\title{
Factors Determining the Profitability of Catfish Production in Ibadan, Oyo State, Nigeria
}

\author{
Oluwasola O. ${ }^{1} \&$ A. O. Ige ${ }^{1}$ \\ ${ }^{1}$ Department of Agricultural Economics, Obafemi Awolowo University, Ile-Ife, Nigeria \\ Correspondence: Oluwasola O, Department of Agricultural Economics, Obafemi Awolowo University, Ile-Ife, \\ Nigeria. Tel: 234-803-727-4784. E-mail: oluwemimo_oluwasola@yahoo.com
}

Received: June 8, 2015 Accepted: July 9, 2015 Online Published: September 4, 2015

doi:10.5539/sar.v4n4p57 URL: http://dx.doi.org/10.5539/sar.v4n4p57

\begin{abstract}
This study evaluated the socioeconomic factors influencing the profitability of catfish production in the city of Ibadan. Multistage sampling method was used to collect data from 120 fish farmers. Descriptive statistics, budgetary analysis and the multiple regression model were used to analyse the data obtained. The results showed that catfish production in Ibadan was male dominated as $80 \%$ of the fish farmers were men. The mean age of fish farmers was $44.3 \pm 12.0$ years while as many as $78.3 \%$ of the farmers had post-secondary education. The mean family size was $5.2 \pm 1.9$ while fish farmers were small operators with a mean farm size of $0.3 \pm 0.2$ hectares. Fish farming is very recent as farmers had a mean farm experience of $6.9 \pm 6.5$ years. Eighty per cent of the fish farmers got involved in fish farming for commercial reasons. The gross margin to catfish farming was $\$ 197,520.25$ (US\$ 987.60)/ha with a net income of $\$ 182,573.04$ (US\$912.87)/ha. The budgetary analysis revealed that fish feed which constituted $79.18 \%$ of the total operating cost was the major cost item in catfish production. The regression analysis showed that fish farming experience, amount of labour used and quantity of feed used were significant determinants of net income in catfish production. The study concluded that there is the need to access fish farmers to substantially cheaper feed inputs to ensure the use of adequate quantity and quality of feed in catfish production. This will enhance output, productivity and net income in catfish enterprises.
\end{abstract}

Keywords: Catfish, feed, unemployment, nutrition, policies, disincentive, subsistence, livelihood

\section{Introduction}

The enormous opportunities presented by increasing urbanization in Nigeria can be exploited by policy makers and agricultural sector operators to meet the challenges of unemployment, poverty and inadequate nutrition that pervades Nigerian cities. This is because the cities offer large markets, cosmopolitan and affluent population that demands more and better nutrition, and growing industrial and service sectors that depend on the agricultural sector for raw materials. Recent figures on the level of unemployment in Nigeria which stood at $23.9 \%$ in 2011(National Bureau of Statistics \{NBS\}, 2012; CIA, 2014) as well as urban unemployment estimated at 29.5\% in 2013 (This Day, 2015) has been unacceptably high. Coupled with this is the challenge of poverty which also stood at 69\% (112.5 million people) of the estimated national population of 163 million (NBS, 2014a). The NBS (2014b) also puts youth unemployment at 54\% (with $48.1 \%$ male and $51.9 \%$ female). Furthermore, the average protein intake in Nigeria is about $19.38 \mathrm{grams} / \mathrm{caput} / \mathrm{day}$ which is far below the Food and Agricultural Organization's (FAO) requirement of $75 \mathrm{~g} /$ caput/day (FAO, 1995).

Although the intensity of urban growth can pose a major challenge to the development and growth of large scale farming, fish production is an enterprise that requires small areas of land and which can make use of the several stream channels for the sustainability of the urban environment. In Nigeria where most of the cities have large agricultural resources and potentials relative to the industrial and service sectors, fish farming can generate significant employment, provide income earning potentials for the urban population, enhance the socio-economic status of the farmer as well as generate foreign exchange (Oluwasola \& Ajayi, 2013; Olagunju, et al., 2007; Adekoya \& Miller, 2004; Eyo, 1992). As succinctly put by Pretty et al. (2003), with dwindling food production, degrading agricultural environment, widespread poverty and insecurity in Africa, fish farming provides the poor and hungry with a low cost and readily available strategy to increase food production using less land and less water without further damage to the environment. Fish farming also has enormous potentials of improving the nutritional standard of the masses of the people. Fish contains higher percentage of protein than 
meat and is important for its high nutritive value and significance in improving human health. Faced with increasing wealth, changing dietary patterns and urbanization, fish farming provides the key to meeting fish demand in the face of dwindling fish supply from captured sources. Fish farming is not just uniquely placed to reverse the declines in supplies experienced from capture fisheries but also has notable potentials for new livelihood opportunities, providing mechanism for lower priced fish, enhanced nutritional security and employment for poor communities (Jagger \& Pender, 2001).

Prior to the 1990s, the development of fish farming in Nigeria was driven by socio-economic objectives including, nutrition improvement of rural communities, generation of additional family income, creation of employment and diversification of income generating activities. Fish farming was promoted by International Organizations and agencies as well as the governments of Nigeria at Federal, State and Local Government levels. In Nigeria, fish farming is predominantly an extensive land based system, practiced mainly at subsistence levels in fresh waters (Anyawu-Akeredolu, 2005). However, only a few species such as catfish and tilapia are cultured commercially (Komolafe and Arawomo, 2007) as commercial farming is yet to become widespread (Fagbenro, 2005). At present, most fish farmers operate small-scale farms ranging from homestead concrete ponds ( 25 - 40 meters) to small earthen ponds ( $0.02-0.2$ hectares). The industry produced over 85,000 tonnes of fish in 2007 (FDF, 2008). FAO (2005b, 2006b) pointed out that Nigeria with extensive mangrove ecosystem and over 14 million hectares of inland water surface out of which 1.7 million are available and suitable for fish farming, should not have any major challenge in achieving sufficient and sustainable fish output to meet domestic demand. Yet, in spite of the nations enormous fish potentials and increasing interests in the subsector (Tobor, 1990; Shimang, 2005; Welcome, 1979; Kapetsky, 1981), the gap between the demand for fish in Nigeria (1.3 million metric tonnes annually) and its supply from domestic production (about 0.45 metric tonnes annually) has continued to widen (Oluwasola \& Ajayi, 2013). This study thus seeks to evaluate the socioeconomic factors influencing the profitability of catfish production in the city of Ibadan with a view to determining its effects on employment generation, poverty alleviation and enhanced nutrition among the urban population. Specifically, the paper described the socioeconomic characteristics of fish farmers in the city of Ibadan, analyzed costs and returns to catfish farming and determined the factors affecting the profitability of catfish production.

\section{Methodology}

The study was carried out in the city of Ibadan, Oyo State in the in the southwestern geopolitical zone of Nigeria. The city is located on the coordinates of longitude $3^{0} 5$ ' East of the Greenwich Meridian and latitude $7^{0} 23^{\prime}$ North of the Equator. Administratively, the city is divided into eleven local government areas (LGAs) and has a population of 1,338,659 (NPC, 2006). Ibadan is the largest traditional city south of the Sahara (UN-Habitat, 2001) and is connected by road, rail and air transport to several cities in the southwestern geopolitical zone. The city enjoys two climatic seasons -the rainy season which lasts from April to October and the dry season which lasts from November to March. The city experiences a mean annual rainfall of $1,262 \mathrm{~mm}$ and a temperature range of between $22.5^{\circ} \mathrm{C}$ and $27.5^{\circ} \mathrm{C}$ (Oguntoyinbo, 1994).

Primary data were used for the study. A multistage sampling procedure was used to select respondents for the study. In the first stage, the city of Ibadan was purposively selected because of the large and ready market for a burgeoning fish farming enterprise. At the second stage, six of the eleven LGAs including: Egbeda, Ido, Ibadan North-West, Ona-Ara, Ibadan North and Ibadan North East were randomly selected while from a list of catfish farmers obtained from the State Agricultural Development Programme (ADP), twenty catfish farmers were randomly selected from each LGA. In all, 120 catfish farmers were sampled for the study.

Data collected were analysed with descriptive statistics, budgetary techniques and the multiple regression model. Descriptive statistics including frequency counts, means and percentages were used to describe the socio-economic characteristics of the catfish farmers while the budgetary technique was used to determine the gross margin and profitability of catfish enterprises. The profit was estimated:

$$
\pi_{i}=P_{i} Q_{i}-T C i
$$

where,

$$
\begin{aligned}
\pi_{i} & =\text { net income }(\mathrm{N}), \\
P_{i} & =\text { price per kg of fish produced }(\mathrm{N}), \\
Q_{i} & =\text { Fish output }(\mathrm{kg}), \text { and }, \\
T C i & =\text { total costs of production (fixed cost }\{\mathrm{FC}\} \text { plus variable cost }\{\mathrm{VC}\})(\mathrm{N}) .
\end{aligned}
$$


Variable costs (VC) included in the analysis were expenditures on labour, feed, fingerlings, broodstock, fertilizer, lime, transportation, drugs and security. Items that could be used for more than a production cycle were classified as fixed costs (FC). These included nets, plastics and depreciation on pond construction, generator and pumping machines.

A multiple regression model was used to determine the factors affecting net income from catfish farming in the city of Ibadan. The model was implicitly specified as:

$$
\mathrm{Y}=\mathrm{f}\left(\mathrm{X}_{1}, \mathrm{X}_{2}, \mathrm{X}_{3}, \mathrm{X}_{4}, \mathrm{X}_{5}, \mathrm{X}_{6}, \mathrm{X}_{7}, \varepsilon_{i}\right)
$$

where,

$\begin{aligned} \mathrm{Y} & =\text { Net income }(\mathrm{ha}) \\ \mathrm{X}_{1} & =\text { Age of farmer (Years) } \\ \mathrm{X}_{2} & =\text { Family size } \\ \mathrm{X}_{3} & =\text { Farming experience (Years) } \\ \mathrm{X}_{4} & =\text { Size of fish pond }\left(\mathrm{m}^{2}\right) \\ \mathrm{X}_{5} & =\text { Labour (man days) } \\ \mathrm{X}_{6} & =\text { Quantity of feed used }(\mathrm{kg}) \\ \mathrm{X}_{7} & =\text { Educational level of respondent (Years) } \\ \varepsilon_{i} & =\text { Error term }\end{aligned}$

The implicit function was linearized and specified in a log-linear form (Joshi \& Jha, 1992; Idumah, 2006) as:

$$
\operatorname{LnY}=\beta_{0}+\beta_{1} \mathrm{X}_{1}+\beta_{2} \mathrm{X}_{2}+\ldots \ldots \ldots \ldots \ldots . .+\beta_{7} \mathrm{X}_{7}+\varepsilon_{\mathrm{i}}
$$

According to Greene (2005) and Gujarati (2003), the disturbance term is expected to fulfil all the assumptions of clssical regression model except that of homoscedasticity which breaks down when cross-sectional data are used (Ayanwale and Osotimehin, 2001). The technique of the ordinary least square (OLS) was then used to estimate the multiple regression equation. Rather than a straight line, geometric interpretation of the model involved a plane. The strength of the relationship between net income from catfish production and the specified explanatory variables was therefore measured by the $\mathrm{R}^{2}$.

A priori expectations were for $\mathrm{X}_{1}, \mathrm{X}_{3}, \mathrm{X}_{4}, \mathrm{X}_{5}, \mathrm{X}_{6}$ and $\mathrm{X}_{7}$ to be positively associated with net income while $\mathrm{X}_{2}$ could be positively or negatively associated with net income depending on whether the family is a production or consumption unit. The selection of the variables used in the regression model as well as the a priori expectations were based on the assumption that in traditional and near subsistent farming enterprises characterised by low resource inputs, age $\left(\mathrm{X}_{1}\right)$, family size $\left(\mathrm{X}_{2}\right)$, farming experience $\left(\mathrm{X}_{3}\right)$, labour (hired and family labour) $\left(\mathrm{X}_{5}\right)$ and educational level of respondents $\left(\mathrm{X}_{7}\right)$ are critical to output (Akinola \& Adeyemo, 2008; Aihonsu, 2002; Oluwasola, 1996; Olayide et al., 1981) and the ability of farmers to take risks in adopting new innovations or technologies (Feder et al., 1985; Adesina \& Zinnah, 1992;). Other studies on fish farming like (Olaoye et al., 2013; Ifejika et al., 2007; Olagunju et al., 2007) added other inputs such as feed $\left(\mathrm{X}_{6}\right)$ and pond size $\left(\mathrm{X}_{4}\right)$. The selection of these variables followed after these earlier studies. Three functional forms of the regression model linear, semi-log and the double logarithm were fitted to the model but only the double logarithm model which provided the best fit and was in line with a priori expectation was selected and discussed.

\section{Results and Discussions}

\subsection{Socio-economic Characteristics of Cat Fish Farmers}

Table 1 shows that majority of the fish farmers (33.3\%) aged between 41 and 50 years with an age range of between 23 and 65 years. The mean age of the farmers was $44.3 \pm 12.0$ years. The fish farmers as indicated were in their prime age and hence, economically active (Aihonsu \& Olatingiri, 2012; Fregene et al., 2011). Given necessary resources, these set of farmers could increase their productivity. They are also in the age where they could take risks that could increase output as well as income (Akinola \& Adeyemo, 2008; Adesina \& Zinnah, 1992; Feder et al., 1985). Eighty percent of the fish farmers were men while the remaining $20 \%$ were women. The dominance of men in fish production was also reported by Fregene et al. (2011). The dominance of the male gender could be due to a number of factors including the access to water points as access to land is through male lineage (Oluwasola, 1998) and is only by purchase that women can have access to such land resources. It could also be because of the drudgery of fish farming. However, the number of women involved is significant in a region where women are more involved in commerce than in production. 
Table 1. Socio-economic characteristics of respondent farmers

\begin{tabular}{|c|c|c|c|c|}
\hline Variable & Frequency & Percentage & Mean & Standard Deviation \\
\hline \multicolumn{5}{|l|}{ Age (Years) } \\
\hline$\leq$ & 20 & 16.7 & & \\
\hline $31-40$ & 29 & 24.2 & & \\
\hline $41-50$ & 40 & 33.3 & 44.3 & 12 \\
\hline $51-60$ & 16 & 13.3 & & \\
\hline$\geq 61$ & 15 & 12.5 & & \\
\hline \multicolumn{5}{|l|}{ Gender } \\
\hline Male & 96 & 80.0 & & \\
\hline Female & 24 & 20.0 & & \\
\hline \multicolumn{5}{|l|}{ Level of education } \\
\hline Did not go to school & 2 & 1.7 & & \\
\hline Primary school education & 1 & 0.8 & & \\
\hline Secondary school education & 23 & 19.2 & & \\
\hline Tertiary education & 94 & 78.3 & & \\
\hline \multicolumn{5}{|l|}{ Marital Status } \\
\hline Single & 35 & 29.2 & & \\
\hline Married & 81 & 67.5 & & \\
\hline Separated & 4 & 3.3 & & \\
\hline \multicolumn{5}{|l|}{ Family size } \\
\hline$\leq 5$ & 59 & 49.2 & & \\
\hline $6-10$ & 61 & 50.8 & 5.2 & 1.9 \\
\hline \multicolumn{5}{|l|}{ Farm Size (ha) } \\
\hline$\leq 0.5$ & 110 & 91.7 & & \\
\hline $0.51-0.75$ & 3 & 2.5 & & \\
\hline $0.76-1.00$ & 6 & 5.0 & 0.3 & 0.2 \\
\hline$\geq 1.01$ & 1 & 0.8 & & \\
\hline \multicolumn{5}{|c|}{ Farming experience of farmers (years) } \\
\hline$\leq 5.0$ & 68 & 56.7 & & \\
\hline $5.1-10.0$ & 35 & 29.2 & & \\
\hline $10.1-15.0$ & 5 & 4.2 & 6.9 & 6.5 \\
\hline $15.1-20.0$ & 7 & 5.8 & & \\
\hline$\geq 21$ & 5 & 4.1 & & \\
\hline
\end{tabular}

\begin{tabular}{lrc}
\hline Occupational status in fishing & & \\
\hline Primary occupation & 53 & 44.2 \\
Secondary occupation & 67 & 55.8 \\
\hline Source of beginning capital & & \\
\hline Savings & 69 & 57.5 \\
Family & 30 & 25.0 \\
Friends & 8 & 6.7 \\
Cooperatives & 11 & 9.2 \\
$\quad$ Commercial bank & 2 & 1.7 \\
\hline Reasons for farming & & \\
\hline Subsistence & 24 & 20.0 \\
Demand for fish & 69 & 57.5 \\
Price & 27 & 22.5 \\
\hline
\end{tabular}

Source: Field survey, 2014 
As shown in Table 1, majority of the fish farmers were educated with as much as $78.3 \%$ having attended Universities, Polytechnics and Colleges of Education. Fregene et al. (2011), Fregene and Digun-Aweto (2008) also reported high levels of education among fish farmers in Oyo and Osun States of the country. Clearly, these set of farmers were educated farmers seeking to tap into the rich fish market to make financial gains. Only $1.7 \%$ of them did not go to school. Majority (67.5\%) of them were married (Adewuyi et al., 2010) hence, could easily make use of family labour to perform critical farm tasks. It however also means that they will incur higher household expenditure that will reduce the quantum of income realizable from the enterprise. The mean family size was $5.2 \pm 1.9$ while fish farmers were small operators with a mean farm size of $0.3 \pm 0.2$ hectares. Fish farm sizes were small because most of the farmers had no access to credit funds to invest in the enterprise (Adeoti et al., 2011; Okorie, 1998; Olomola, 1990). Only 2.7\% got loans from commercial banks while $9.2 \%$ got loans from cooperative societies to start the business. The remaining relied on their personal savings $(57.5 \%)$, family members $(25 \%)$ and friends $(6.7 \%)$. About $86 \%$ of the farmers have been involved in fish farming for not more than 10 years with a mean farm experience of $6.9 \pm 6.5$ years. Clearly, catfish farming is a recent phenomenon (Aihonsu \& Olatingiri, 2012). Although all the respondents had other economic activities they were engaged in aside from fish farming, 55.8\% were engaged in the business on part time basis as they saw it as a secondary occupation while the remaining said fish farming was their primary occupation even though they had other businesses. Clearly, fish farming provided opportunities for expanding livelihood choices in the city of Ibadan as fish farmers were also able to engage in other income earning activities after taking care of their fish farms. The push factors for engaging in fish farming as shown in Table 1 were threefold: the increasing demand for fish (57.5\%); the high price catfish commands in the market (22.5\%) and for subsistence (20\%). Clearly, $80 \%$ of the fish farmers got involved for commercial reasons.

\subsection{Profitability of Cat Fish Farming}

The average income from cat fish enterprises in the city of Ibadan was $\$ 630,049$ (US\$ 3,150.25) (Table 2) while the total average variable cost to enterprise was $\$ 432,528.75$ (US\$ 2,162.64) given a gross margin of $\$ 197,520.25$ (US\$ 987.60). The average total cost was $\$ 447,475.96$ (US\$2,237.38) giving a net income of $\$ 182,573.04$ (US\$912.87). This amounts to a monthly income of about $\$ 15,214.42$ which is less than the national minimum wage of $\$ 18,000$; (US\$76.07). Clearly, the high capital investment required and the low net income realizable is a disincentive to attracting young unemployed people. This is partly why in spite of the enormous opportunities in producing fish to meet the gap in supply, the fish subsector has not succeeded in attracting local investors. Only the employed with the necessary financial resources who needs to augment incomes from other economic activities to meet family expenditure are attracted. Table 2 clearly shows that the cost of feed for the fish constitute $79.2 \%$ of the total operating cost. Any policy and/or technical measure that substantially reduces the cost of feeding the fish will substantially increase farm income and hence profit. Labour cost constituted only $11.6 \%$ of operating cost. The low cost could have resulted from the use of family labour by majority of the fish farmers who were married with fairly large family sizes as shown in Table1.Other cost components were very low .

The financial ratios shows that the expense-structure ratio was 0.03 indicating that for every $\$ 100$ spent on fish farms, $\$ 3$ was incurred on fixed inputs while $\$ 97$ was spent on variable inputs. This suggests that farmers can easily adjust to variations in market conditions as variable costs constitute the largest proportion of farm expenditure. However, it also implies that oscillations in the market price of variable inputs could impact gross margin realizable. Policies that will lead to a reduction in the costs of these inputs, particularly feed will significantly reduce the cost of production and make the enterprise profitable. The benefit - cost ratio of 1.41 suggests that every $\$ 100$ invested in fish farming will yield an additional income of $\$ 41$. 
Table 2. Analysis of cost and returns to fish farming

\begin{tabular}{|c|c|c|}
\hline Income/cost Items & Amount $(\mathbb{N})$ & Percentage in cost category \\
\hline Revenue & $630,049.00$ & \\
\hline \multicolumn{3}{|l|}{ Variable Costs } \\
\hline Labour & $(50,141.67)$ & 11.6 \\
\hline Feed & $(342,250.00)$ & 79.2 \\
\hline Fingerlings & $(14,250.00)$ & 3.3 \\
\hline Broodstock & $(4,593.33)$ & 1.1 \\
\hline Fertilizer & $(2,139.17)$ & 0.5 \\
\hline Lime & $(758.33)$ & 0.2 \\
\hline Drugs & $(5,157.92)$ & 1.2 \\
\hline Transportation & $(11,475.00)$ & 2.7 \\
\hline Security & $(1,763.33)$ & 0.4 \\
\hline Total variable costs & $(432,528.75)$ & \\
\hline Gross margin & $197,520.25$ & \\
\hline \multicolumn{3}{|l|}{ Fixed costs items } \\
\hline Nets & $(2,958.34)$ & 19.8 \\
\hline Plastics & $(1,108.42)$ & 7.4 \\
\hline Depreciation & $(10,880.45)$ & 72.8 \\
\hline Total fixed cost & $(14,947.21)$ & \\
\hline Total Cost & $(447,475.96)$ & \\
\hline Net revenue & $182,573.04$ & \\
\hline Expense-Structure Ratio & & 0.03 \\
\hline Benefit-Cost Ratio & & 1.41 \\
\hline
\end{tabular}

Source: Field Survey, 2014.

\subsection{Factors Determining the Profitability of Cat Fish Farms}

Equation 3 shows that all the independent variables with the exception of farming experience $\left(\mathrm{X}_{3}\right)$ were positively signed in conformity with a priori expectations. Farming experience $\left(\mathrm{X}_{3}\right)$ was not in conformity with a priori expectations as it was negatively signed. Three of the variables, farming experience of respondents $\left(\mathrm{X}_{3}\right)$, labour used $\left(\mathrm{X}_{5}\right)$ and quantity of feed used $\left(\mathrm{X}_{6}\right)$ were also statistically significant.

The experience of respondents in catfish farming $\left(\mathrm{X}_{3}\right)$ in contrast to a priori expectations was negatively signed although statistically significant. The coefficient of the variable indicates that a unit increase in the experience of catfish farmers will depress income by 13\%. This result contradicts findings by Adesiyan and Idowu (2011) and Oluwasola, (2011). Three things could have accounted for this. First, as farmers age, their fish ponds also tend to become older and except remedial actions are taken to keep the fish dams from siltation, productivity could decrease as pond sizes also decrease. Secondly, as farmers age and their children are out of the homes for schools resulting in reduced family labour, the increasing need for labour decreases interest in fish farming. In addition reduced household size which also means a reduction in household expenditure all things being equal could lead to a reduction in efforts put into fish farming. Finally and more critically, when farmers do not find fish farming to be economically rewarding over time, their interest in the enterprise could wane thereby affecting output. The amount of labour used $\left(\mathrm{X}_{5}\right)$ was statistically significant with its coefficient indicating that an increase in labour used by a man-day will increase net income by $12.3 \%$ (Bamire et al., 2008). This is very important as labour is the most important input in smallholder farm business enterprises. The quantity of feed used $\left(\mathrm{X}_{6}\right)$ was also positively associated with net income from catfish farming (Oluwasola \& Ajayi, 2013). The coefficient of the variable indicates that a kilogram increase in fish feed used will increase net income by $83.7 \%$.

The adjusted coefficient of determination of $\mathrm{R}^{2}$ value of 0.915 indicates that about $91.5 \%$ of the variability in the net income realized from cat fish farming in the city of Ibadan are determined by the explanatory variables specified in the model. 


$$
\begin{aligned}
& \ln \mathrm{Y}=4.799+0.089 \ln \mathrm{X}_{1}+\quad 0.059 \ln \mathrm{X}_{2}-\quad * 0.133 \ln \mathrm{X}_{3}+0.022 \ln \mathrm{X}_{4}+* * 0.123 \ln \mathrm{X}_{5} \\
& \begin{array}{lllll}
(0.079) & 0.044) & (0.072) & (0.024)
\end{array} \\
& +* * * 0.837 \ln \mathrm{X}_{6} \quad+0.210 \ln \mathrm{X}_{7} \\
& (0.028) \quad(0.167) \\
& \mathrm{R}^{2} \quad=0.862 \\
& \overline{\mathrm{R}}^{2}=0.854 \\
& \text { F-value }=97.187
\end{aligned}
$$

N.B. Figures in parenthesis are the standard errors

*significant at $10 \%$ level; ** significant at $5 \%$ level; *** significant at $1 \%$ level

\section{Conclusion and Recommendation}

The study has shown that catfish enterprises are recent means of livelihood among middle age and highly educated male urban dwellers who although have other means of livelihood, are engaged in catfish farming to augment household income and for subsistence. While supply of fish could enhance the nutrition of households engaged in catfish farming, it could also be targeted by policy to engage unemployed educated youths in the urban centres. Such farmers should be accessed to inputs of feed, credit and water points to enable them engage in the enterprise profitably. The net income realizable for engaging in catfish farming were however too low to attract the unemployed young, able bodied and educated urban dwellers to engage in the enterprise. A major way out of this challenge is to access potential farmers to cheaper feed to enhance the profitability of the enterprise. This could come in two main ways: stemming up research efforts to produce viable fish feed locally as a way out of the high costs of imported feeds or subsidizing fish feed. Nigeria produces only $13.4 \%$ of her fishmeal requirements and imports the remaining (Fagbenro \& Adebayo, 2005). The major commercial fishmeal processing plant has since closed down because it cannot compete with imported fishmeal. In 2004, the cost of imported fishmeal ranged between US\$870 and US\$1, 350 per tonne, while the cost of locally produced fishmeal was US\$1,500 per tonne (Fagbenro and Adebayo, 2005). Nigeria currently imports about 40,000 metric tonnes $(44,444.44$ tonnes) valued at US\$ 60 million (Global Agricultural Information Network $\{$ GAIN\}, 2011). Cheaper fish feed will also help retain experienced fish farmers as the net income realized from the enterprise will increase. It will also enhance the quantity as well as the quality of feeds given the fish for increased output and productivity.

The positive but significant association between labour used and net income shows the importance of labour to the production efforts of smallholder farmers. The low cost component of labour in catfish farm enterprises suggests that farmers depended more on family labour which is not sustainable in the long term as family members settle outside the family households. It also suggests that farming was on small scale and oriented mainly for subsistence with marketable surplus exchanged for cash. There is the need for policy measures to attract medium to large scale farmers into the catfish enterprise not only to increase output to bridge the supply gap but also to provide employment for the unemployed urban youths.

\section{References}

Adekoya, B. B., \& Miller, J. W. (2004). Fish Cage Culture Potential in Nigeria: An Overview. National Culture, Agricultural Focus, 1(5), 10-18.

Adeoti, A., Cofie, O., \& Idowu, O. (2011). Sustainability of Urban Agriculture in Ibadan, Nigeria: Gender Analysis of Livelihoods. In R. Adeyemo (ed.), Urban Agriculture, Cities and Climate Change (pp. 173-178). CuvillierVerlag, Gottingen.

Adesina, A. A., \& Zinnah, M. M. (1992). Technology Characteristics, Farmers Perceptions and Adoption Decisions: A Tobit Model Application in Sierra Leone (pp. 297-311). Agricultural Economics, Elsevier Science Publishers, B.V., Amsterdam.

Adesiyan, A. T., \& Idowu, E. O. (2011). Urban Agriculture and Household Food Security in Lagos Metropolis, Nigeria. In R. Adeyemo (ed.) Urban Agriculture, Cities and Climate Change (pp. 132-137). CuvillierVerlag, Gottingen.

Adewuyi, S. A., Phillip, B. B., Ayinde, I. A., \& Akerele, D. (2010). Analysis of Profitability of Fish Farming in Ogun State, Nigeria. Journal of Human Ecology, 31(3), 179-184. 
Aihonsu, J. O. Y. (2002). Comparative Economic Analysis of Upland and Swamp Rice Production Systems in Ogun State, Nigeria. Unpublished Ph.D Thesis. Department of Agricultural Economics, Obafemi Awolowo Universty, Ile-Ife, Nigeria.

Aihonsu, J. O. Y., \& Olatingiri, O. A. (2012). Analysis of Socio-economic Characteristics for Policy Enactment; The Case of Artisanal Fisherfolks in Ibeju-Lekki Local Government Area of Lagos State, Nigeria. In Refereed Conference Proceedings of the Nigerian Association of Agricultural Economists (NAAE) pp107112

Akinola, A. A., \& Adeyemo, R. (2008). Adoption and Productivity of Improved Rice Varieties in Osun State, Nigeria. Ife Journal of Agriculture, 23(1), 104-116.

Anyawu-Akeredolu, B. (2005). Urban aquaculture in Nigeria. World Aquaculture Society. Annual Report. Retrieved from www.was.org/meetings/abstract data

Ayanwale, A. B., \& Osotimehin, K. O. (2001). A Comparative Analysis of Savings Behaviour of Small-scale Farmers and Low Income Industrial Workers in Lagos State of Nigeria. Ife Research Publication in Geography, 8, 10-17.

Bamire, A. S., Akinola, A. A., Olubode-Awosola, O. O., \& Oyewusi, G. (2008). Comparative Economic Analysis of Crop-Livestock Integration among Smallholder Maize Farmers in the Derived Savanna Zone of Southwestern Nigeria". Ife Journal of Agriculture, 23(1), 86-103.

CIA. (2014). World Factbook, 2014.

Eyo, A. A. (1992). Utilization of Freshwater Fish Species in Nigeria. In A. A. Eyo \& A. M. Balogun (Eds.), Proceedings of the 10th Annual Conference of the Fisheries Society of Nigeria (pp. 32-38).

Fagbenro, O. A. (2005). Aquaculture in Nigeria: history, status and prospects. A report of FAO World Fish Centre Workshop. Cameroon.

Fagbenro, O. A., \& Adebayo, O. T. (2005). A review of the animal and aquafeed in Nigeria. In A synthesis of the formulated animal and aquafeed industry in Sub-Sahara Africa. CIFA Occasional Paper No 26 P2C 36.

FAO. (1995). Yearbook Production. Rome: FAO. p. 45.

FAO. (2005b). Small Scale Aquaculture in Sub-Saharan Africa. Revisiting the Aquaculture Target Group Paradigm. Rome: FAO Fisheries.

FAO. (2006b). Fisheries Management in the Federal Republic of Nigeria. Retrieved from www.fao.org/fi/fep/en/NGA/body

Feder, G., Just, R. E.., \& Zilberman, D. (1985). Adoption of Agricultural Innovations in Developing Countries: A Survey". Economic Development and Cultural Change, 33(2), 255-298. http://dx.doi.org/10.1086/451461

Federal Department of Fisheries (FDF). (2008). Fisheries Statistics of Nigeria. Fourth edition, 1995 - 2007, Nigeria (p. 48).

Fregene, T., Inyang, I., \& Awolumote, S. (2011). Operational Attributes of Urban Aquaculture Systems in Ibadan Municipal, Oyo State, Nigeria. In R. Adeyemo (ed.), Urban Agriculture, Cities and Climate Change, (pp. 173-178). CuvillierVerlag, Gottingen.

Fregene, T., \& Digun-Aweto, T. (2008). Use of Aquaculture Technologies in Osun State, Nigeria. African Journal of Livestock Extension, 6, 36-41.

Global Agricultural Information Network (GAIN) (2011) Exporter Guide for Nigeria. (2011). USDA, Foreign Agricultural Service, 24/6/2011.

Greene, W. H. (2005). Econometric Analysis. Pearson Education Publishers, India.

Gujarati, D. N. (2003). Basic Econometrics. Tata McGraw-Hill Publishing Company Limited, India.

Idumah, F. O. (2006). Productivity Differentials among Food Crop Farmers in the Niger Delta. Unpublished Ph.D Thesis, Department of Agricultural Economics, University of Ibadan, Ibadan.

Ifejika, P. I., Ayanda, J. O., \& Sule, A. M. (2007). Socio-Economic Variables affecting Aquaculture Production Practices in Borgu Local Government Area of Niger State, Nigeria. Journal of Agriculture and Social Research, 7(2), 20- 9. http://dx.doi.org/10.4314/jasr.v7i2.2853

Jagger, P., \& Pender, J. (2001). Markets, Marketing and Production Issues for Aquaculture in East Africa: The Case of Uganda. ICIARM Quart, 24, 42-51. 
Joshi, P. K., \& Jha, D. (1992). An Economic Enquiry into the Impact of Soil Alkalinity and Water Logging. Indian Journal of Agricultural Economics, 47(2), 195-204.

Kapetsky, J. M. (1981). Some Consideration for the Management of Coastal Lagoon and Estuarine Fisheries. FAO Technical (p. 218).

Komolafe, O. O., \& Arawomo, G. A. O. (2007). Reproductive Strategy of Oreochromisniloticus in Opa Reservoir, Ile-Ife, Nigeria. Rev. Biol. Trop., 55, 595-602. http://dx.doi.org/10.15517/rbt.v55i2.6034

National Bureau of Statistics (NBS). (2012). The Nigeria Poverty Profile. NBS, Abuja.

National Bureau of Statistics (NBS). (2014a). The Nigerian poverty profile 2010, NBS, Abuja.

National Bureau of Statistics (NBS). (2014b). 2012 National baseline youth report, NBS/Federal Ministry of Labour and Productivity, Abuja.

National Population Commission. (2006). Nigeria's National Census, NPC, Abuja.

Oguntoyinbo, J. S. (1994). Climatic Characteristics. In M. O. Filani \& F. O. Akintola (Eds.), Ibadan Region (pp. 37-48). Rex Charles Publications, Ibadan.

Okorie, A. (1998). Management of Risks and Defaults in Agricultural Lending. In M. A. Ijere \& A. Okorie (Eds.), Readings in Agricultural Finance. Longman, Nig. PLC, Lagos.

Olagunju, F. I., Adesiyan, I. O., \& Ezekiel, A. A. (2007). Economic viability of catfish production in Oyo - State. Nigeria Journal of Human Ecology, 21(2), 121-124.

Olaoye, O. J, Ashley-Dejo, S. S, Fakoya, E. O, Ikeweinwe, N. B, Alegbeleye, W. O., Ashaolu, F. O., \& Adelaja, O. A. (2013). Assessment of Socio-Economic Analysis of Fish Farming in Oyo State, Nigeria. Global Journal of Science Frontier Research Agriculture and Veterinary, 13(9), 1-12.

Olayide, S. O., Eweka, J. A., \& Bello-Osagie, V. E. (1981). Nigerian Small Farmers: Problems and Prospects in Integrated Rural Development (pp. 1-64). Caxton Press (West Africa) Limited, Ibadan.

Olomola, A. S. (1990). Loan Transaction Cost and Repayment Performance and Small scale Farmers in Ondo State, Nigeria. Unpublished Ph.D. thesis, Department of Agricultural Economics, University of Ibadan, Nigeria.

Oluwasola, O., \& Ajayi, D. (2013). Socio-economic and Policy issues Determining Sustainable Fish farming in Nigeria. International Journal of Livestock Production, 4(1), 1-8. http://dx.doi.org/ 10.5897/IJLP12.013

Oluwasola, O. (1998). Women in Agriculture in Nigeria. In A. Sesay \& A. I. Odebiyi (Eds.), Women in Society and Development (pp. 59-72). Dokun Publishing House, Ibadan, Nigeria.

Oluwasola, O. (2011). Peri-urban farming in Ibadan metropolis. In R. Adeyemo (ed.), Urban Agriculture, Cities and Climate Change (pp. 96-103). CuvillierVerlag, Gottingen, Germany.

Pretty, J. N., Morison, J. I. L., \& Hine, R. E. (2003). Reducing Food Poverty by Increasing Agriculture Sustainability in Developing Countries. Agric. Ecosyst. Environ., 95, 217-234. http://dx.doi.org/10.1016/S0167-8809(02)00087-7

Shimang, G. N. (2005). Fisheries Development in Nigeria: Problems and Prospects. Paper presented at the Homestead Fish Farming Training for Serving and Retired Public Servants, Federal Ministry of Agriculture and Rural Development, Abuja, Nigeria.

This Day. (2015). Nigeria's unemployment may rise by 2\%. Retrieved May 15, 2015, from www.thisdaylive.com

Tobor, J. G. (1990). The Fish Industry in Nigeria: Status and Potential for Self-sufficiency in Fish Production. NIOMR Technical, 54, 34.

UN-HABITAT. (2001). Cities in a Globalizing World: Global Report on Human Settlements". United Nations for Human Settlement (Habitat), Earth scan Publications Ltd., London.

Welcome, R. I. (1979). The Inland Fisheries of Africa. CIFA Occasional, 7, 77.

\section{Copyrights}

Copyright for this article is retained by the author(s), with first publication rights granted to the journal.

This is an open-access article distributed under the terms and conditions of the Creative Commons Attribution license (http://creativecommons.org/licenses/by/3.0/). 